\title{
IMPLEMENTASI BUDIDAYA TERIPANG DI DESA MADWAER, MALUKU TENGGARA
}

\section{Pitjont Tomatala *}

Politeknik Perikanan Negeri Tual

\section{Meyske Angel Rahantoknam}

Politeknik Perikanan Negeri Tual
ABSTRACT: IMPLEMENTATION OF SEA CUCUMBER CULTIVATION IN MADWAER VILLAGE, SOUTHEAST MALUKU. Sea cucumbers or Teripang (Holothuria $s p$ ) is a fishery commodity that has economic value. Sea cucumbers are often caught and sold by a group of people in Madwaer village, Southeast Maluku regency. The value of perceived benefits motivates them (partners) to try to cultivate sea cucumbers by utilizing the coastal conditions in their village. Limitations of knowledge about the technique of making cucumber cultivation container, technology of sea cucumber rearing and management of sea cucumber business is a problem faced by partners. This activity aims to help partners solve the problems faced. The method used in this activity is elucidation, training and monitoring. From the results of the activity is known that partners have had the knowledge and skills so that they are able to make a good cultivation cucumber container, able to cultivate sea cucumbers and partners are able to do the management of sea cucumber business well.

KEYWORDS: Cultivation, Holothuria sp, Sea Cucumber.

* Corresponding Author: Teknologi Budidaya Perairan, Politeknik Perikanan Negeri Tual; Jl. Raya Langgur-Sathean KM. 06, Sathean, Kei Kecil, Kabupaten Maluku Tenggara, Maluku; Email: pitjont_82@yahoo.com

Article History: Received: 16-10-2017; Revised: 15-11-2017; Accepted: 28-11-2017

Permalink: http://ppm.ejournal.id/index.php/pengabdian/article/view/26

How to cite (APA): Tomatala, P., \& Rahantoknam, M. A. (2017). Implementasi budidaya teripang di desa Madwaer, Maluku Tenggara. Jurnal Pengabdian Pada Masyarakat, 2(2), 135-140.

This is an open access article distributed under the terms of the Creative Commons Attribution 4.0 International License, which permits unrestricted use, distribution, and reproduction in any medium, provided the original work is properly cited. @ 2017, Pitjont Tomatala, Meyske Angel Rahantoknam.

\section{PENDAHULUAN}

Teripang atau dikenal dengan nama timun laut termasuk dalam kelas Holothuria. Biota laut jenis ini benilai ekonomis tinggi dan mempunyai prospek yang baik dipasaran domestik maupun internasional. Teripang harganya cukup mahal yaitu berkisar Rp. 400.000,- s/d Rp. 2.000.000,- per kg kering. Kandungan nutrisi yang baik yang dimiliki teripang (Protein 43\%, lemak 2,2\%, kadar air 27,1\% dan kadar abu 27,6\%) menyebabkan teripang banyak ditangkap dan dimanfaatkan sebagai bahan makanan yang mengandung nutrisi tinggi dan juga digunakan untuk bahan baku obat-obatan (Hendri, Sunaryo, \& Pahlevi, 2009). Kandungan gizi dan bahan bioaktif yang terkandung dalam teripang dapat mengontrol glukosa darah, 
sehingga teripang dapat mengatasi gangguan diabetes mellitus (Karmila, 2013), sebagai antibakteri dan antikapang (Karnila, 2011; Padang, Lukman, \& Sangadji, 2014; Padang, Lukman, \& Sangadji, \& Subiyanto, 2016). Teripang juga mengandung senyawa anti bakteri (holotoksin), sehingga dapat menghambat aktivitas bakteri pathogen (Kustiariyah, 2007)

Desa Madwaer merupakan salah satu desa yang terdapat di Kabupaten Maluku Tenggara, Propinsi Maluku. Desa ini memiliki perairan bersubstrat pasir putih yang ditumbuhi lamun (seagrass) dan ditemukan teripang pasir/putih (Holutria scabra) hidup di sana. Di saat Musim Timur (bulan April-Oktober) perairan desa ini mengalami hempasan gelombang yang relative kuat sedangkan pada Musim Barat (Oktober-April) perairannya teduh bagaikan minyak. Meskipun ditejang gelombang pada Musim Timur namun ada beberapa titik pada perairan desa ini agak terlindung dari terpaan gelombang. Perairan tersebut belum dimanfaatkan secara baik untuk kegiatan budidaya terlebih khusus budidaya teripang. Beberapa anggota masyarakat yang sudah merasakan manfaat penjualan teripang melalui hasil pengumpulan di alam, memiliki keinginan kuat untuk melakukan budidaya teripang di areal tersebut. Harapannya melalui kegiatan budidaya teripang dapat meningkatkan pendapatan masyarakat dan sumberdaya alam di desa mereka tetap terjaga.

Permasalahan yang dihadapi yaitu keterbatasan pengetahuan baik pengetahuan mengenai cara pembuatan wadah budidaya teripang, teknologi pembesaran teripang dan pengetahuan manajemen usaha teripang yang baik. Keterbatasan pengetahuan yang dihadapi coba diatasi dengan kehadiran Tim Pengabdi. Pengetahuan yang dibagikan merupakan hasil penelitian yang telah dilakukan oleh Tim Pengabdi. Harapannya Tim Pengabdi dapat membantu mitra menyelesaikan masalah-masalah mitra baik aspek produksi maupun aspek manajemen usaha budidaya teripang sehingga dapat menggairahkan dan meningkatkan pendapatan mitra.

\section{METODE PELAKSANAAN}

Untuk mencapai tujuan yang diharapkan, program pengabdian kepada masyarakat ini dilaksanakan dengan menggunakan metode sebagai berikut:

Penyuluhan, bertujuan memberikan pengetahuan teoritis kepada mitra mengenai pembuatan wadah budidaya, teknik pembesaran dan manajemen usaha budidaya teripang. Dalam proses penyuluhan disiapkan ruang untuk melakukan 
tanya jawab sehingga mempermudah pemahaman mitra terhadap materi yang disampaikan.

Pelatihan, merupakan tindak lanjut dari penyuluhan. Tujuan pelatihan yaitu untuk menambah keterampilan mitra tentang pembuatan wadah budidaya, teknik pembesaran teripang dan manajemen usaha budidaya teripang.

Monitoring, metode ini bertujuan memberikan pendampingan dan bimbingan kepada mitra berkaitan dengan permasalahan yang dihadapi dalam pembuatan wadah budidaya, teknik pembesaran dan manajemen usaha budidaya teripang.

\section{HASIL DAN PEMBAHASAN}

\section{Pembuatan Pen-culture}

Kurungan tancap (Pen-culture) yaitu area budidaya yang dipagari menyerupai kurungan agar teripang tidak dapat meloloskan diri. Tim pengabdi membuat Pen-culture sebanyak 4 buah berukuran 3 x 2 x 0,7 m (Gambar 1). Penculture yang dibuat merupakan hasil penelitian ketua Tim Pengabdi yang diaplikasikan kepada mitra karena kondisi perairan desa mitra yang semi terbuka. Pembuatan Pen-culture dilakukan bersama mitra dan berlangsung selama 2 hari. Pembuatan Pen-culture membutuhkan waktu yang cukup lama disebabkan karena hanya dapat berlangsung pada saat air laut surut terendah. Adapun tahapan pembuatan Pen-culture sebagai berikut:

1) Pemilihan lokasi budidaya yang sesuai ketentuan teknis budidaya teripang.

2) Pemilihan peralatan dan bahan yang baik untuk pembuatan Pen-culture.

3) Pemotongan dan peruncingan kayu tancap.

4) Penancapan kayu tancap pada lokasi yang telah ditentukan dan pembuatan konstruksi.

5) Penggalian dasar perairan dan pemasangan waring/jaring sepanjang konstruksi Pen-culture yang berfungsi sebagai pagar/pembantas.

6) Pembuatan penutup Pen-culture dan digunakan untuk menutup Pen-culture. 


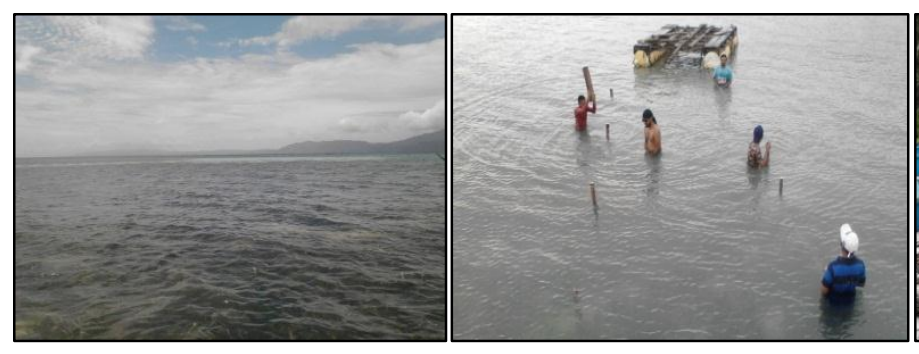

Pemilihan Lokasi

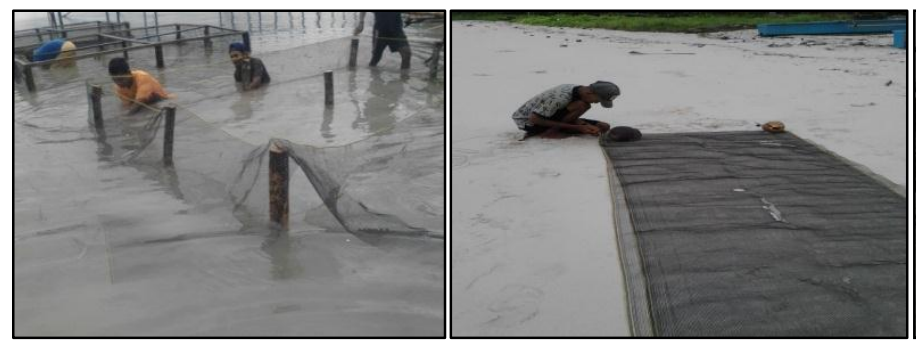

Pemasangan Jaring
Pembuatan Penutup Pen-culture

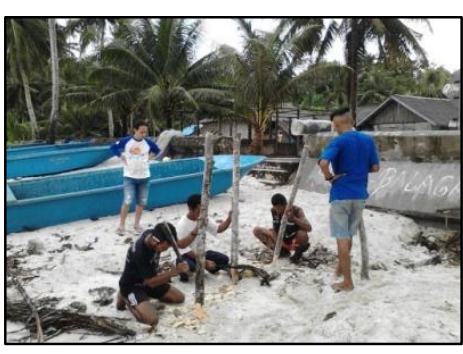

Penancapan Kayu

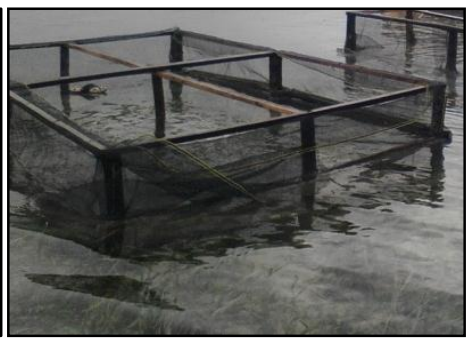

Pen-culture telah Siap

Gambar 1. Proses Pembuatan Pen-culture

\section{Pemeliharaan Teripang}

Teripang yang dipelihara oleh mitra diambil dari alam. Teripang dikumpul pada kotak styrofoam (Gambar 2a) dan dingakut ke tempat pemeliharaan. Pada proses ini, mitra diajarkan bagaimana transportasi teripang hidup secara baik. Proses pengangkutan perlu diperhatikan dengan baik karena sangat berpotensi menyebabkan teripang stress bahkan menyebabkan kematian. Pada saat akan melakukan penebaran teripang pada tempat pemeliharaan, mitra diajarkan cara penebaran teripang secara baik (Gambar 2b). Pada saat penebaran teripang, Tim Pengabdi menunjukan ke mitra karakteristik benih teripang yang baik. Pemeliharaan teripang hingga penen membutuhkan waktu minimal delapan (8) bulan, sehingga pengontrolan terhadap biota yang dipelihara dan wadah budidaya perlu dilakukan secara terus menerus.

Selain pengontrolan, teripang juga diberi pakan tambahan guna membantu menyediakan makanan bagi teripang, sehingga pertumbuhan teripang dapat optimal. Pakan tambahan yang diberikan berupa campuran kotoran sapi dan batang pisang (Musa. sp). Batang pisang dirajang supaya ukurannya lebih kecil kemudian dimasukan ke dalam karung (Gambar 2c) dan dicampur dengan kotoran sapi dengan perbandingan 2:1 (2 kg batang pisang dicampur dengan $1 \mathrm{~kg}$ kotoran sapi). Kotoran sapi berfungsi membantu mempercepat proses pembusukan batang 
pisang, sehingga banyak terdapat detritus (sisa-sisa pembusukan bahan organik) yang dapat dikomsumsi oleh teripang. Teripang tergolong organisme laut pemakan detritus, organik debris, dan plankton (Aziz, 1996).

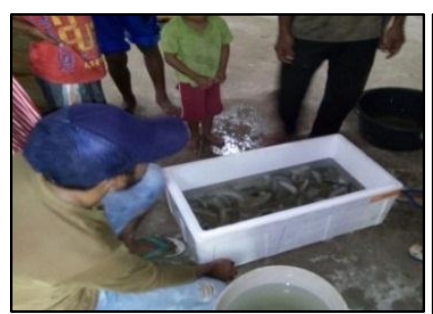

(a)

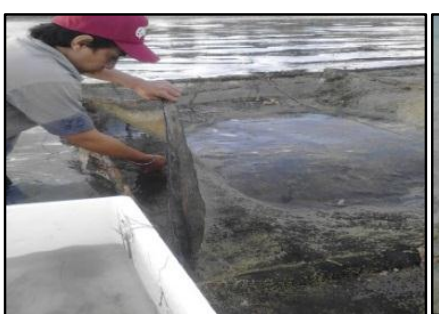

(b)

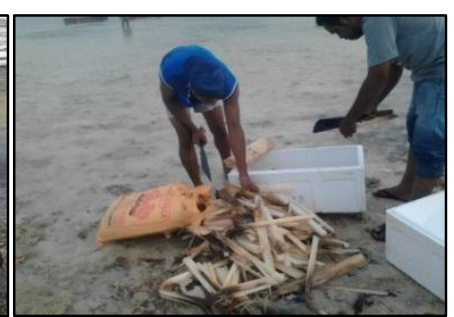

(c)

Gambar 2. Proses Pemeliharaan Teripang

\section{Manajemen Usaha Budidaya Teripang}

Manajemen usaha budidaya bertujuan agar mitra mampu untuk mengelola usaha budidaya teripang dengan baik sehingga dapat mencapai keuntungan. Kegiatan ini dimulai dari mitra diberi pemahaman terlebih dahulu mengenai cara mengelola organisasi dengan baik dalam hal ini manajemen kepemimpinan serta distribusi pekerjaan yang merata disetiap fungsi dan tugas setiap anggota. Setelah itu, dilanjutkan dengan kegiatan pelatihan pembukuan sederhana dimana mitra diajarkan tentang bagaimana mengidentifikasi biaya baik biaya tetap seperti peralatan Pen-culture serta pembelian benih teripang maupun biaya variabel seperti bahan bakar, konsumsi maupun biaya pemasaran.

Setelah mitra paham tentang bagaimana mengidentifikasi biaya, maka selanjutnya dilakukan pelatihan perhitungan laba rugi dengan cara yang sangat sederhana, dimana keuntungan diperoleh dari total penjualan dikurangi dengan biaya usaha. Pelatihan ini diharapkan mitra akan lebih terampil dalam manajemen usaha, seperti sistem pembukuan usaha walaupun secara sederhana, sehingga ke depan usaha budidaya teripang yang dijalankan dapat terus berlanjut dan memperoleh keuntungan.

\section{SIMPULAN}

Hasil pembahasan menunjukkan bahwa transfer ilmu dan keterampilan mengenai pembuatan wadah budidaya teripang, teknologi budidaya teripang dan manajemen usaha teripang di desa Madwaer terlaksana dengan baik dan mitra sudah dapat mengaplikasikan ilmu dan keterampilan yang diperoleh.

Pendampingan dan monitoring agar dilakukan secara berkelanjutan. Selain itu, perhatian Pemerintah Daerah juga dibutuhkan, sehingga kegiatan budidaya 
teripang dapat berlangsung berkesinambungan dan menjadi sumber pendapatan tetap bagi masyarakat desa Madwaer, Kabupaten Maluku Tenggara.

\section{REFERENSI}

Ahmad, W. (2013). Budidaya teripang, khasiat dan cara olah untuk pengobatan. Yogyakarta: Pustaka Baru Press.

Aziz, A. (1996). Makanan dan cara makan berbagai jenis teripang. Oseana, 21(4), 4359.

Hendri, M., Sunaryo, A. I., \& Pahlevi, R. Y. (2009). Tingkat kelulusan hidup larva teripang pasir (holothuria scabra, jaeger) dengan perlakuan pemberian pakan alami berbeda di balai besar pengembangan budidaya laut (BBPBL) Lampung. Jurnal Penelitian Sains, 12(1), 1-5.

Karmila, A. (2013). Efek pemberian teripang pasir (Holothuria scabra) terhadap profil imunohistokimia antioksida superoksiada dismutase (SOD) pada pankreas tikus diabetes. (Skripsi) Institut Pertanian Bogor, Bogor, Indonesia.

Karnila, R. (2011). Potensi ekstrak, hidrolisat dan isolat protein teripang pasir (Holothuria scabra J.) untuk menurunkan kadar glukosa darah dan memperbaiki profil sel beta pankreas tikus diabetes melitus. Laporan Penelitian Hibah Bersaing Universitas Riau.

Kustiariyah. (2007). Teripang sebagai sumber pangan dan bioaktif. Buletin Teknologi Hasil Perikanan, 10(1), 1-8.

Padang, A., Lukman, E., \& Sangadji, M. (2014). Pemanfaatan diatom bentik sebagai makanan teripang dalam rangka pengembangan usaha budidaya teripang. Paper presented at Seminar Nasional Penguatan Pembangunan Berbasis Riset Perguruan Tinggi (SPP-RPT) I (pp. 264-270).

Padang, A., Lukman, E., Sangadji, M., \& Subiyanto, R. (2016). Pemeliharaan teripang pasir (Holothuria scabra) di kurungan tancap. AGRIKAN Jurnal Ilmiah Agribisnis dan Perikanan, 9(2), 11-18.

Serang, A. M., Rahantoknam, S. P. T., \& Tomatala, P. (2014). Pengaruh padat tebar terhadap pertumbuhan dan sintasan anakan teripang Holothuria scabra. In A. Subekti, \& H. Sonjaya (Eds.), Penguatan pembangunan nasional berbasis riset multidisiplin perguruan tinggi. Paper presented at Seminar Nasional Penguatan Pembangunan Berbasis Riset Perguruan Tinggi (SNPP-RPT) I, Universitas Darussalam Ambon, Ambon, 8 November 2014 (pp. 277-282). Ambon: Pusat Penelitian Universitas Darussalam Ambon. 